\title{
輸入リスクアセスメントとその量的モデル
}

小河 孝*1, 衛藤真理子*2, 畠山英夫*3

\section{Import risk assessment of animals and animal products and it's model}

\section{はじめに}

1993年12月のガットウルグアイラウンド農業合意 による世界貿易機構 (WTO)協定を構成するSPS 協定 (衛生及び植物検疫措置適用に関する協定)によ って, 動物検疫を含む検疫・衛生措置は「国際基準 が存在する場合には自国の検疫・衛生措置を国際基 準に基づかせることを原則とするが，科学的正当性 がある場合には国際基準よりも厳しい措置を採用で きる」等, 現在の国際的規律の下でわが国のそれも 新たな対応が求められている。さらに SPS 協定は動 物検疫について, リスクアセスメントの方法を考慮 して「検疫・衛生措置が人または動物の生命, 健康 に与えるリスクの評価に基づくことを確保する」と し, 国際獣疫事務局 (OIE) が示したリスクアセスメ ントのガイドラインに沿って加盟各国が独自にその 手法の開発をはかるとしている。このような状況を ふまえ, 現在わが国でも関係機関で輸入リスクアセ スメント手法の開発に着手している。

本報告はそれら一連の開発の基本となる OIEの ガイドラインおよびカナダ, ニュージーランド等に おける輪入リスクアセスメントに関する先導的な考 え方を紹介し，まとめたものである。

\section{輸入リスクアセスメントに閏するこれまでの経過}

1990年, ガットは貿易にかかわる非関税障壁を取 り除く立場から OIEに対し「動物の防疫措置が貿易 の不当な障害とならぬよう輪入規制の適切性につい て家亩衛生上許容可能な水準の概念とこれを評価す

*1 農林水産省家畜衛生試験場九州支場 ₹891-01 鹿児島市中山町2702

*2 農林水産省家畜衛生試験場総合診断研究部度学研究 室 干305 つくば市観音台3-1-1

*3 中央畜産会情報部

于 105 東京都港区虎/門 1-26-5
るためのガイドラインの開発」を目的とする要請を 行なった。

1991年, OIE は「動物の輸入に係わるリスクアセ スメント(危険度評価)」という文書を年次総会に提 案し，その中で輪入リスクアセスメントとは「動物 および畜産物を介して家畜伝染病が輸入国に侵入す る危険度の推定を数值化して評価し, その結果に基 づいて輸入の可否を決定する」と定義している。

1992年, OIE の年次総会で加盟18か国が提案する 「動物および畜産物の国際貿易における衛生上の危 険度分析およびその取り扱い」と題する報告 ${ }^{1)}$ が Kellar(カナダ農業食料省)によって行われた。以下 にその概要を示す。

1) 各国は, 自国に存在しない疾病または防疫対策 の対象疾病の浸入を防止する固有の権利を有して いる。

2) いっぽう，防疫对策を確実にするための輸入の 絶対的禁止（いわゆるゼロリスク）政策は，国内に おける家畜の生産性の改善を阻害し, 消費者の期 待を消失させ，国際的な貿易活動と両立しがたい。 3 ）以上の弊害を避けるため, 動物および畜産物の 輸入に関連した危険度を量的に評価する「輸入リ スクアセスメント」を採用する必要がある。

4 ）その意思決定過程の最も有効な手段は, 輪入単 位に由来する病原体浸入の可能性を「輸出国にお ける疾病の流行と輸入国においてそれによって暴 露される動物の頭数の可能性の関数」として計算 する。

5 ）そのためには，十分な量の客観的デー夕の蓄積 が必要であり, 家畜衛生と畜産統計, 診断技術, 疫学手法の改善とサーベイランスとモニタリング システムの確立が重要である。

1993年, OIE 総会は第4次本会議一専門委員会(国 際家畜衛生規約委員会：コード委員会)に,「輸入危 
険度分析」に関する一般的考察(第1.4.1章) (案)を 提出した。論議の中で, 日本代表は「輸入の結果生 じる疾病の浸入にともなう経済的損失に言及する」

(第1.4.1.1条)と「輸入国において採用している衛生 措置を輸出国についても同様に採用することが要求 できる」(第1.4.1.6条)の2点をこの文書に加えるこ とを主張した。しかし, 討論採決の結果, 第1.4.1章 は原文のまま採択された(日本代表は棄権)。

現在，オーストラリア，カナダ，二ュージーラン ド，米国等を中心に「輸入リスクアセスメント」に 関する協同作業が行われており，わが国でも関係機 関を中心にその手法の開発がす寸められている。

\section{リスクアセスメントに䦌連する用語の定获}

\section{Agent : 病原体}

OIEのリスト $\mathrm{A}$ および $\mathrm{B}$ 疾病の発生と流行の原 因となる病原微生物。

Animal import unit(AIU) : 功物輪入単位

生体もしくは畜産物の重量を動物頭数に換算する 単位。動物 1 頭, 受精卵・精液 1 頭分および 1 頭か ら生産される苗産物の製品重量を 1AIUとする。

Average duration of infection (ADI) : 平均感染期 間

Average hard size (AHS) : 平均群サイズ

農場 (農家)1戸当たりの平均飼養頭 (羽) 数。

\section{Calculated prevalence：計算有病莗}

Case fatality rate(CFR) : 致死事

No. of cases：発生報告された頭羽数

Commodity : 商品

輪入のための動物，その生産物および副産物。

Country factor(CFI)：国の要因

輸入動物が感染している確率に影響をおよぼす輸 出国特有の要因。すなわち輸出国における家畜感染 病の流行状況がそこに反映されている。

\section{Country factor(CF2)：商品の要因}

もし輸入動物が感染していた場合, 輸入時に病原 体が存在する確率に影響をおよぼす要因もしくはそ の確率。

Disease course(DC)：有病期間

Incubation period(IP)：潜伏期間

Latent infection(니) : 潜在感染

LIS (Latenty infected survivors)：潜在感染した 功物の生残率

Latent period(LP)：潜在感染の报大期間

No. of outbreaks : 発生件数
Population : 感受性峌物の餇举頭数

Probability of agent entry(PAE) : 輪入国への病 原体侵入の確率

少なくとも $1 \mathrm{AIU}$ の輸入商品が污染している確率。 Probability of domestic exporsure(PDE)：㻌入国 における病原体基蜜の確事

病原体が輸入国の感受性動物の感染経路に暴露さ れる確率。

Risk：リスク(危險度)

ある行為によって生じる不利益事象の確率。例之 ば，特定の商品の輸入にともない家畜感染病が国内 に侵入し，発生する危険率。発生(罹患)率, 死亡率, 致死率等が含まれる。

Risk analysis : リスク分析

リスク評価，リスク伝達およびリスク管理を包括 するもの。

Risk assessment : リスクアセスメント(危険度評 価)

商品の輸入にともなうすべてのリスクの結果を統 計的確率過程で計算すること。

Risk communication : リスク伝達

産業および食品分野の関係者に対して商品のリス ク評価を伝えること。

Risk management : リスク管理

商品を最終的に輸入するか否かの決定およびリス ク軽減措置の過程。

Unrestricted risk estimate (URE) : 非制限的リ

スク評価

商品がいかなるリスク軽減措置もなされない通常 の形態で輪入された場合のリスク評価。

\section{リスクアセスメントにおける疾病発生の喜象と確事 および統計学的背景}

生きた動物もしくは畜産物を1AIU 輸入すること により，以下に述べる事象と状態を経過して最終的 に疾病発生事象 $(\mathrm{O})$ に帰着する場合,

A-1AIUの商品が病原体に污染される。

$\mathrm{B}$-病原体が商品の扱い, 処理もしくは輸送の過程で 生き残る。

C-商品が感受性動物もしくは人に暴露される。

$\mathrm{D}$-病原体が侵入門戸で暴露され, 伝播経路を介して 拡散する。

$\mathrm{E}$-病原体が感染を引き起こす(病原体の侵入，展開 および増殖)。

F-感染が疾病を引き起こす。 
G-疾病が拡散する。

$\mathrm{H}$-疾病の顕在化。

の過程をへて，事象が生起する確率は以下のように 定義される。

$\mathrm{P}(\mathrm{O})$ は $1 \mathrm{AIU}$ の商品輸入によって疾病の発生が 起こる確率で, $\mathrm{P}(\mathrm{O})=\mathrm{P}(\mathrm{A}) \times \mathrm{P}(\mathrm{B} \mid \mathrm{A}) \times \mathrm{P}(\mathrm{C} \mid$ $\mathrm{A} \cap \mathrm{B}) \mathrm{x} \mathrm{P}(\mathrm{D} \mid \mathrm{A} \cap \mathrm{B} \cap \mathrm{C}) \mathrm{x} \cdots \times \mathrm{P}(\mathrm{H} \mid \mathrm{A} \cap \mathrm{B} \cap$ $\mathrm{C} \cap \mathrm{D} \cap \mathrm{E} \cap \mathrm{F} \cap \mathrm{G})$ と表わされる。

$\mathrm{P}(\mathrm{A})$ は，上述したように，1AIU の商品が病原体に 污染する確率で，それは輸出国における疾病の有病 率で示めされる。

$\mathrm{P}(\mathrm{A} \mid \mathrm{B})$ は, 1AIU の商品が污染している場今に, 病原体が生き残る条件確率を示している。

$\mathrm{P}(\mathrm{C} \mid \mathrm{A} \cap \mathrm{B})$ は, 1AIU の商品が污染しかつ病原 体が生き残る場合に，感受性動物および人が商品に 暴露される条件確率を示している。

以下，同様に過程で示すことができる。また，も L1AIU の商品が輪入時に病原体に污染している場 合に, 国内で感染が起こると仮定し， $\mathrm{P}(\mathrm{O})$ を疾病が 摘発(診断)できる確率と定義すると，

$\mathrm{P}(\mathrm{O})=\mathrm{P}(\mathrm{I} \cap \mathrm{X})=\mathrm{P}(\mathrm{I}) \mathrm{xP}(\mathrm{X} \mid \mathrm{I})$ と表わすこと ができる。

$\mathrm{P}(\mathrm{I})$ は, 1AIU の商品が輸入時に病原体に污染し ている確率,

$\mathrm{P}(\mathrm{X} \mid \mathrm{I})$ は，その場合における，病原体による暴 露, 伝播, 発病そして疾病の顕在化の条件確率で示 される。

$\mathrm{P}(\mathrm{I})=1-\mathrm{P}(\overline{\mathrm{I}})=1-\mathrm{P}($ 輪入時に商品が污染されて ない確率)でも表わされる。

さらに, 輪入時に $n \mathrm{AIU}$ の商品のうち $x \mathrm{AIU}$ が感 染している場合，その確率を二項分布 (binomial distribution) で示すと,

$$
\begin{gathered}
P(X)=\frac{n !}{x !(n-x) !} p^{x} q^{n-x} \quad p: \text { 輸入時における感染率 } \\
\text { (母感染率) } \\
q=1-p: \text { 同じく非感染率 } \\
n: \text { 商品の AIU 数 } \\
x: \text { 商品中の感染数 }
\end{gathered}
$$

もし, 輸入時に商品の感染がなければ $x=0$ とな $\eta$, その確率は $p(0)=q n=(1-p) n$ となる。

いっぽう, 輸入時に $1 \mathrm{AIU}$ 以上の感染が起こる確 率は, $P(x \geqq 1)=1-q n=1-(1-p) n$ となり, 次項 で述べる

$\mathrm{PAE}$ (輪入国への病原体侵入の確率 $)=1-(1-$ $\mathrm{CF} 1 \mathrm{xCF} 2)^{\mathrm{nAIU}}$ 式を $\mathrm{CF} 1 \mathrm{xCF} 2=p$ に置き換えれば前
式と同じになる。

\section{量的リスクアセスメトモデル}

Morley の報告2)を中心に筆者らの若千のコメン 卜を加えて紹介したい。

\section{1. 非制限的リスクアセスメント}

輪入に伴う疾病リスクの確率は簡単な数学モデル で推定できる。すなわち, 非制限的りスク評価 (Unrestricted risk estimate：URE)は通常の商業形態 における商品輸入にともなうリスクとして得られる。 その非制限的リスクとは診断や検疫などのようなリ スク軽減させる措置を選択する以前のそれをさす。 URE は輪入国への病原体侵入の確率 $(\mathrm{PAE})$ と輪入 国における病原体の暴露の確率 (PDE)の積で表わ される。すなわち, $\mathrm{URE}=\mathrm{PAE} \mathrm{x} \mathrm{PDE}$ となる。

\section{2. 輸入国への病原体侵入の確率(PAE)}

$\mathrm{PAE}$ は少なくとも1動物輸入単位 $(\mathrm{AIU}) の$ 商品 が感染(污染)している確率である。それは国の要因 (Country factor: CF1) と商品の要因 (Commodity factor：CF2) および動物輸入単位数 (nAIU)によっ て, $\mathrm{PAE}=1-(1-\mathrm{CF} 1 \times \mathrm{CF} 2)^{\mathrm{nAIR}}$ で表わされる。

\section{3 . 国の要因(CFI)}

輸入商品の量的リスクアセスメントにおいて輸出 国における疾病の存在とその水準がこの要因の基本 となる。大量の輸入の場合は，関連する動物集団に おける有病率(Prevalence)の情報が必須条件にな る。しかし少量の輸入の場合は, Uとつの群 (Hard) の，その中における小集団(Group)あるいは特定の 飼育形態もしくは地域における動物の有病率の情報 の方がより的確となる。国全体の有病率は群や小集 団のそれとは明らかに相違がある。しかし OIEの疾 病発生報告システムは国を基本単位としているので, 輸入国は輸出国全体の疾病発生状況をもとにして輸 入リスクアセスメントを行わざるをえない。

\section{4 . 有病率の算出方法}

1) OIEのリスト A 疾病(ブルータングを除く)の 場合

(1) 最近に発行されたOIEの World Animal Healthもしくは Bulletin から12か月間の発生 件数 (No. of outbreaks)の統計を求める。

(2) 同じく特定の動物種の飼養頭数 (Popula- 
tion)を求める。それを群の数で割って平均群サ イズ (AHS) を求める。

（3）表 1 に示したように，リスト $\mathrm{A}$ 疾病の平均感 染期間 $(\mathrm{ADI})$ を求め，365日でそれを割って年 換算の ADI を求める。

疫学では, 発病から死亡あるいは治癒転帰までの 期間を示す有病期間 (Disease course：DC)は年換 算 $\mathrm{DC}=\mathrm{DC} / 365$ で表わし, 発生率 (Incidence rate : IR) と有病率(PrevaIence rate:PR)の関係は $\mathrm{PR}=\mathrm{IR} \times \mathrm{DC}$ で示すことができる。

例えば，表1に示すように，アフリカ豚コレラの有 病期間を急性型を 7 日 (年換算 $\mathrm{DC}=7 / 365=1.92$ $\mathrm{x} 10^{-2}$ )，慢性型を 730 日 (年換算 $\mathrm{DC}=730 / 365=2.0$ ) であるから， IR $=1.0 \times 10^{-4}$ (1万頭当たり 1 頭の発生) で, 急性型の有病率は $\mathrm{PR}=1.0 \times 10^{-4} \times 1.92 \times 10^{-2}=$ $1.92 \times 10^{-6}$ で慢性型のそれは $\mathrm{PR}=1.0 \times 10^{-4} \times 2.0=$ $2.0 \times 10^{-4}$ となる。有病率は同じ発生率の場合, 慢性型 (有病期間が長い)ほど高い值を示す。また，高い発 生率でも短期間で死亡する急性伝染病では有病率は 低く, 病期の長い慢性伝染病は有病率が高いという 特徴がある。さらに, 有病率 $\mathrm{PR}$ と有病期間 DC が判 明していれば，発生率は $\mathrm{IR}=\mathrm{PR} / \mathrm{DC}$ で推定できる。 Morleyは有病期間の他に感染期間 (Duration of infection：DI)の考之方を導入し，

(a) 最大および最小の潜伏期間 (CP)

(b) すべての病態下における最大および最小の有病 期間 (DC)

(c) 最大および最小の致死率 (CFR)

（d）潜在感染した動物の生残率 (LIS)

(e) 潜在感染の最大期間 (LP)をパラメー夕に用い る （f）感染から潜伏期間を経過して発病, 死亡の転帰 をとる症例の場合，有病期間における平均感染期 問を $\mathrm{ADI}=(\mathrm{IP}+\mathrm{DC}) \times \mathrm{CFR}$ で推定した。

(g) 死亡しないで耐過 $(1-\mathrm{CFR})$ するが潜在感染と ならない $(1-\mathrm{LIS})$ 症例の場合, $\mathrm{ADI}=(\mathrm{IP}+\mathrm{DC}) \mathrm{x}$ $(1-\mathrm{CFR}) \times(1$ - LIS) で推定した。

(h) 発病しないで潜在感染のまま推移する症例の場 合, $\mathrm{ADI}=\mathrm{LP} \times$ LIS で推定した。

（i）上記3種類の ADI を加えて当該疾病の ADI と する。

（j）すなわち, 計算有病率=発生件数 $\mathrm{x}$ AHS x $\mathrm{ADI} /$ 飼養頭数=発生率 $\mathrm{x}$ 年換算 $\mathrm{ADI}$ で表わせる。 この考え方は，潜在感染を特徵とする疾病のリス クアセスメントには合理的であるが, 関連する疫学 指標の把握, 推定が重要となる。OIEリスト $\mathrm{A}$ 疾病 の ADI を表 2 に示した。

具体的計算例として以下の 2 疾病を示す。 牛肺疫の ADI は 120 (年換算0.33)（表 1 ) で, 付録 に示した A 国の1992年の報告によれば牛肺疫の発 生件数10を計算有病率にあてはめると $(10 \times 271$ $\mathrm{x} 0.33) / 23,212,325=3.9 \times 10^{-5}$ と求められる。同様 に, 豚コレラの場合, 発生は86件, ADI は19日 (年換 算0.05)で, 計算有病率は $(86 \times 371 \times 0.05) /$ $26,850,250=5.9 \times 10^{-5}$ となる。豚コレラの場合, 感染 後日数には潜伏期間と疾病経過が含まれている。疫 学指標のうち発生率 (罹患率), 死亡率, 致死率, 有 病率などは, 1 時点, 1 断面の率(Rate)を示すが, それは時点，対象集団，集団サイズによって変化す るものであり，厳密にいえば確率(Probability)では ない。しかし, 一定期間内の累積発生率, 累積死亡 率などは一定期間の発生や死亡の割合(Propor-

表 $1 \mathrm{OIE}$ リストA疾病（牛と豚） 9 種類の疫学パラメー夕による平均感染期間の推定

\begin{tabular}{|c|c|c|c|c|c|c|c|c|c|c|c|}
\hline パラメータ & 口趾 & & 水胞 & E口炎 & 豚水胞病 & 牛疫 & 牛肺疫 & ランピースキン病 & リフトハー熱 & アリリカ豚コラ & 豚コレラ \\
\hline 感染畜種 & 牛 & 豚 & 牛 & 豚 & 豚 & 牛 & 牛 & 牛 & 牛 & 豚 & 豚 \\
\hline 潜伏期間（日） & $1-7$ & $2-8$ & $1-2$ & $1-3$ & $2-14$ & $3-9$ & $21-42$ & $14-28$ & $0.5^{-1}$ & $5-15$ & $2-6$ \\
\hline 致命率（\%） & $2-20$ & $2-20$ & 0 & 0 & 0 & $30-90$ & 50 & 1.5 & $5-10$ & $5-100$ & $95-100$ \\
\hline 有病期間 & & & & & & & & & & & \\
\hline 一甚急型（日） & & & & & & & & & & & $5(\mathrm{PI})^{*}$ \\
\hline －急性型（日） & $4-11$ & 7 & $3-4$ & 14 & $14-21$ & $1-2$ & $7-21$ & 35 & $1-2$ & $5-10$ & $10-20(\mathrm{PI})$ \\
\hline －亜急性型（日） & & & & & & & & & $12-21$ & $21-28$ & $20-29(\mathrm{PI})$ \\
\hline 一慢性型（日） & & & & & & & & & & & $30(\mathrm{PI})$ \\
\hline $\begin{array}{l}\text { 潜伏感染期間（日） } \\
\text { 潜伏感染した動物の }\end{array}$ & 180 & 30 & 0 & 0 & 0 & 0 & $180-1,095$ & 0 & 0 & $180-730$ & $30-120$ \\
\hline 生残率（\%） & 50 & 100 & 0 & 0 & 0 & 0 & 25 & 0 & 0 & 100 & 100 \\
\hline 平均感染期間（日） & 86 & 28 & 5 & 16 & 26 & 17 & 120 & 56 & 3 & 230 & 19 \\
\hline
\end{tabular}

* : PI $=$ post-infection 
tion）を示すもので, これは確率である。また，分婏 子の性比の確率は 0.5 といわれるが, これは無限の分 娩子数で実現されるであろう理念的な常数, すなわ ち母数(Parameter)である。有限の分婏子数では近 似的な值，すなわち尤度 (Likelihood)が得られるだ けで，それは集団のサイズによって変化し，確率そ のものでない。

一般に確率でない率を確率や割合と呼んだり, 確 率でない尤度を確率と呼んだりする混乱や習慣は日 本のみならず諸外国でも根強く残っている。このあ たりの理解や認識の違いが国際的な相互理解の阻害 要因になることはできる限り避けなければならない。 そのためには相互理解可能な論理，すなわち疫学お よび数理統計学の論理に基づく用語の定義が不可欠 であり，たとえ確率といいながらも条件によって変 動する率や尤度には統計的な根拠による変動幅を設 けることが必要である。

2) OIE リスト B 疾病およU゙ブルータング(発生件 数が不明の疾病)の場合

(1) OIEのWorld Animal Healthの発生 (Occurrence) 欄から疾病状態，すなわち例外的
(Exceptional), 散発的 (Low sporadic), 流 行的 (Enzootic) あるいは多発的 (High) を求め る。獣医組織評価の結果に基づいて先の疾病状 態の水準を以下 $3 つ の$ 疾病発生指示に割り当て る。

-suspected but not confirmed(？）：疑われるが 未確定。

-serological evidence and/or isolation causative agent; no clinical disease (+?): 臨床症状は認 められないが, 血清学的には証明でき，そして／あ るいは原因病原体は分離。

-disease exists; distribution and occurrence unknown $(+\cdots)$ : 疾病は存在するが, その分布と発 生は未知。

（2）表 3 から上限有病率, すなわち割当有病率

(Assigned prevalence)を求める。

\section{5. 商品の要因(CF2)}

1）もし動物あるいは畜産物が病原体に污染されて いる場合，輸入国に病原体を持ち込む確率に影響 する動物あるいは畜産物のパラメータで，具体的

表 $2 \mathrm{OIE}$ リスト $\mathrm{A}$ 疾病 (牛と豚) 9 種類の平均感染期間とその年換算値

\begin{tabular}{llcc} 
疾病名 & 畜種 & 平均感染期間 $\mathrm{ADI}($ 日) & $\mathrm{ADI}$ 年換算值 $(\mathrm{ADI} / 365)$ \\
\hline 口蹄疫 & 牛 & 86 & $2.36 \times 10^{-1}$ \\
& 豚 & 28 & $7.67 \times 10^{-2}$ \\
水胞性口炎 & 牛 & 5 & $1.37 \times 10^{-1}$ \\
豚水胞病 & 豚 & 16 & $4.38 \times 10^{-2}$ \\
牛疫 & 豚 & 26 & $7.12 \times 10^{-2}$ \\
牛肺疫 & 牛 & 17 & $4.66 \times 10^{-2}$ \\
ランピースキン病 & 牛 & 120 & $3.29 \times 10^{-1}$ \\
リフトバレー病 & 牛 & 56 & $1.53 \times 10^{-1}$ \\
アフリカ豚コレ & 豚 & 230 & $8.22 \times 10^{-3}$ \\
豚コレラ & 豚 & 19 & $6.30 \times 10^{-1}$ \\
\hline
\end{tabular}

表 3 ブルータングと OIE リスト B 疾病（牛と豚）の各疾病発生水準に対する上側有病率（抜粋）

\begin{tabular}{|c|c|c|c|c|c|}
\hline 疾病名 & 畜種 & 例外的 (exceptional) & 散発的 (sporadic) & 流行的 (epizootic) & 多発的 (high) \\
\hline ブルータングa) & 牛 & $9 \times 10^{-3}$ & $2 \times 10^{-1}$ & $7 \times 10^{-1}$ & $9 \times 10^{-1}$ \\
\hline \multirow[t]{2}{*}{ 炭廈 } & 牛 & $1 \times 10^{-9}$ & $1 \times 10^{-6}$ & $3 \times 10^{-6}$ & $4 \times 10^{-6}$ \\
\hline & 豚 & ND & ND & ND & ND \\
\hline \multirow[t]{2}{*}{ オーエスキー病等 } & 牛 & ND & ND & ND & $\mathrm{ND}$ \\
\hline & 豚 & $2 \times 10^{-4}$ & $2 \times 10^{-1}$ & $5 \times 10^{-1}$ & $6 \times 10^{-1}$ \\
\hline \multirow[t]{2}{*}{ エキノコッカス゚) } & 牛 & $1 \times 10^{-4}$ & $8 \times 10^{-2}$ & $2 \times 10^{-1}$ & $3 \times 10^{-1}$ \\
\hline & 豚 & $1 \times 10^{-4}$ & $1 \times 10^{-1}$ & $4 \times 10^{-1}$ & $6 \times 10^{-1}$ \\
\hline ヨーネ病a,d) & 牛 & $8 \times 10^{-3}$ & $2 \times 10^{-1}$ & $6 \times 10^{-1}$ & $8 \times 10^{-1}$ \\
\hline 結核病e) & 牛 & $1 \times 10^{-5}$ & $7 \times 10^{-2}$ & $2 \times 10^{-1}$ & $3 \times 10^{-1}$ \\
\hline
\end{tabular}

【診断方法】a)：血清抗体による陽性率，b)：発生による有病率， c) ：屠苗検査による有病率

d) : 病変, 寄生虫實血, 病原体分離による有病率, e) : ツベルクリン反応による陽性率 
に,

（1）動物の種類, 年歯および品種

(2) 病原体が存在する部位

(3) 病原体によって污染される程度

(4) $\mathrm{pH}$

（5）加熱処理の温度および時間

(6) 冷凍の温度および時間

（7）保存の温度および時間

(8) 輪送の温度および時間

（9）添加剤および処理

2) CF2の計算法

（1）いずれの処理も行われていない場合あるいは ほとんど影響を与えない場合(一般的に生きた 動物あるいは枝肉) は $\mathrm{CF} 2=1.0$ となる。

(2) 上記の(1)あるいは(2)以降の処理が行われてい る場合は各々の処理による病原体の生存率を乗 ずる。例之ば, $\mathrm{CF} 2=$ 処理(1)による病原体の生存 率 $\mathrm{x}$ 処理(2)による病原体の生存率 $\mathrm{x} \cdots$ 。もし, 処理工程でで病原体を効果的に根絶できる場合 は，10-8の最小確率值を用いることができる。

\section{6. 动物輪入単位 (AIU)}

1 ）特定の重量の製品の生産のために用いられた動 物の頭数を示すために使用する単位で, 動物 1 頭 分に相当する重量をもって1AIUとする。具体例 は以下の通りである。

（1）生きた動物 1 頭=1AIU

（2）受精卵あるいは精液 受精卵 1 個あるいは精 液 1 ストロー= $=1 \mathrm{AIU}$

（3）枝肉 半丸 2 個あるいは動物 1 頭から生産さ れる平均枝肉重量 $=1 \mathrm{AIU}$

（4）部分肉 動物 1 頭から生産される平均部分肉 重量 $=1 \mathrm{AIU}$

（5）八ム 八厶2 本あるいは豚 1 頭から生産され る平均八么重量 $=1 \mathrm{AIU}$

2 ) 動物輸入単位の計算法

$\mathrm{nAIU}=$ 製品の輸入量 /その製品の1AIU 相当量

\section{7 . 暴路の要因(PDE)}

1) もし, 輸入された商品が污染されている場合, それが感受性動物に暴露される確率に影響すると ころの商品の流通, 処理に特有のパラメータで,

(1) 病原体の性質

(2) 輪入の時期

（3）輸入される商品の用途および流通
(4) ベクターの存在

(5) 病原体の一次, 二次および中間ホスト

(6) 輪入される商品の性質

（7）人口および感受性動物の分布

(8) 病原体の伝播方法

（9）食習慣

(10) 家畜衛生法令および実施状況

2) PDEの計算法

動物や畜産物が輸入後に感受性動物に暴露される, すなわち病原体が同時に感受性動物の感染経路に暴 露されるシナリオは無数にある。いずれにせよ感染 の確率は疾病の伝播方法によって大きく左右される。 具体例として,

（1）牛の生体輸入によって, OIEリスト A および $\mathrm{B}$ 疾病は直接接触あるいはべクターによる媒介, 経口感染等の経路で感染する。

(2) 牛および豚肉の輸入によって, 口蹄疫ウイル スは残飯を介して経口感染で豚に感染する。

(3) 牛受精卵の輸入によって, 口蹄疫ウイルスは 直接接触による生殖器感染で牛に感染する。

・商品が生きている動物で輸入される場合

$\mathrm{PDE}=1.0$ で, もし，それが動物園や実験動物等の 用途の場合は家畜との接触機会がないので, この点 は考慮される。また, ベクターによって伝播する疾 病は, ベクターが活動していない時期に動物が輪入 されれると $\mathrm{PDE}=0.0$ となる。

・畜産物が輪入される場合暴露される可能性のシナ リオをすべて書き出し, 各シナリオ毎に暴露確率を 求める。 $\mathrm{PDE}=$ シナリオ 1 の確率 + シナリオ 2 の確 率 $+\cdots$

直接伝播する疾病, 例之ば, 牛肺疫, 牛疫, レプ トスピラ病などについては, $\mathrm{PDE} \fallingdotseq 0$ となる。

\section{8、リスクを低滅させる要因および制限的リスク評 価(RRA)}

1) $\mathrm{PDE}$ の計算によって算出されたUREが大き すぎると判断される場合は, 輸出国あるいは輪入 国で商品に特定の処置を行ってリスクを軽減させ ることができる。具体的に，
(1) 一定の時間と温度による加熱
(2) 一定の時間と温度による保管
(3) 一定の感度試験による診断検查
(4) 農場検疫および出国検疫
（5）おとり動物を用いた検疫
（6）商品用途の限定 
2) CF2と PDE に及ぼす影響

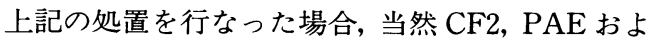
びPDEは処置の影響を踏まえて再度計算を行う。

- $\mathrm{CF} 2{ }^{\prime}=\mathrm{CF} 2 \mathrm{x}$ 処置 1 による病原体の生存率 $\mathrm{x}$ 処置

2による病原体の生存率 $\mathrm{x} \cdots$

- $\mathrm{PAE}^{\prime}=1-(1-\mathrm{CF} 1 \times \mathrm{CF} 2)^{\prime} \mathrm{nAIUs}^{\mathrm{n}}$

- $\mathrm{PDE}^{\prime}=\mathrm{PDE} \mathrm{x}$ 処置 $\mathrm{A}$ による病原体の生存率 $\mathrm{x}$ 処 置 $\mathrm{B}$ による病原体の生存率 $\mathrm{x} \cdots$

3 ) 制限的リスク評価 (RRE)

$\mathrm{RRE}=\mathrm{PAE}^{\prime} \mathrm{x}$ PDE'

\section{引用文献}

1) Kellar, J. A.: The application of risk analysis to international trade in amimals and animal products. Rev. sci. tech. Off. int. Epiz, 12,1023 -1044, 1993.

2 ) Morley, R. S.:A model for the assesment of animal disease risk associated with the importation of animals and animal products. Rev. sci. tech. Off. int. Epiz, 12,1055-1092, 1993. 
COUNTRY: Country A

付録 家畜衛生状況と疾病制圧の方法（人工デー夕）

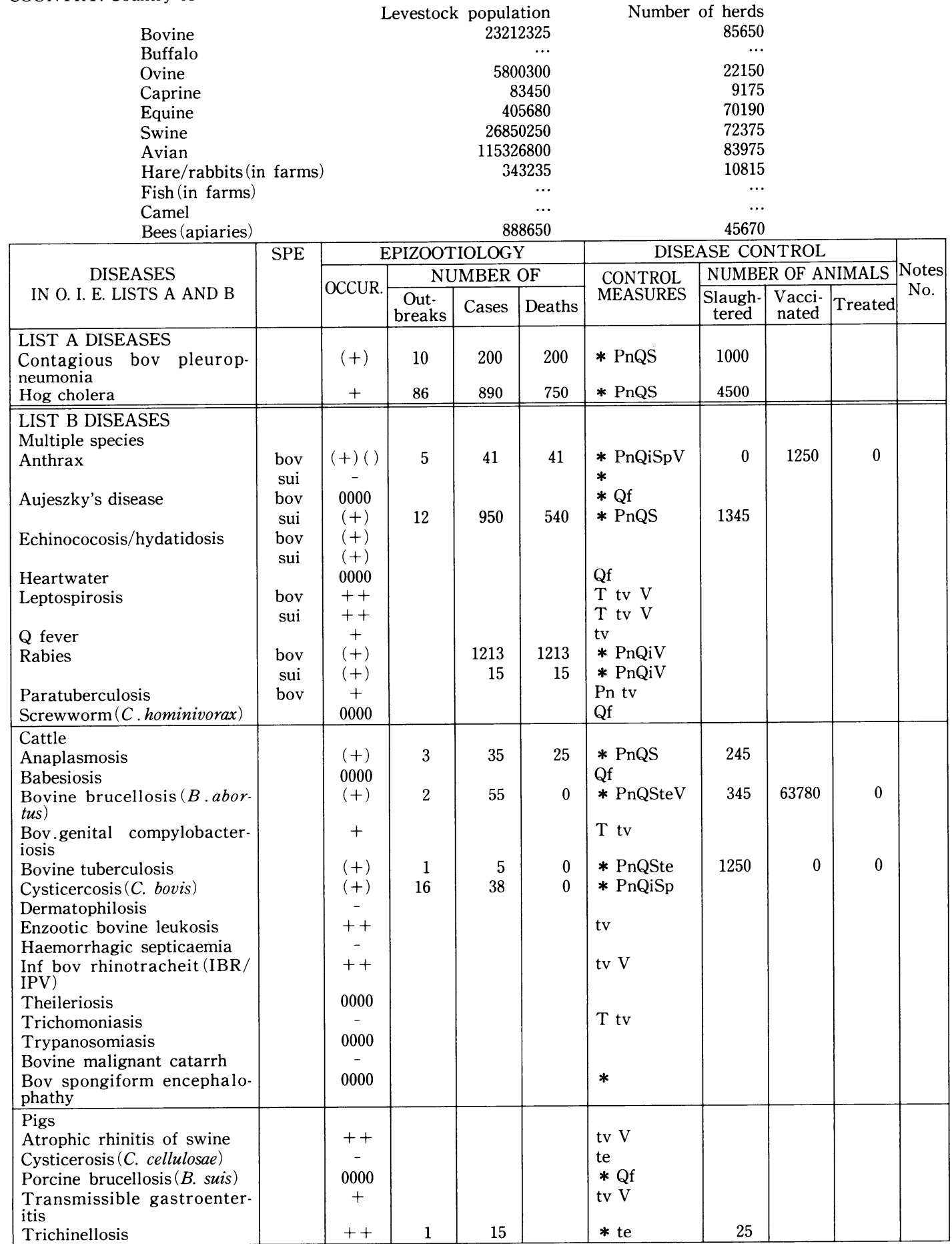




\section{CODES}

Animal group

api

avi

bov

buf

can

cap

$\mathrm{cml}$

equ

fau

fel

lep

ovi

pel

pis

sui

$\mathrm{c} / \mathrm{f}$

$\mathrm{o} / \mathrm{c}$

etc

Disease occurrence 0000

year

?

$(+)$

$+$

$++$

$+++$

+ ?

$+\cdot \cdot$

()

)(

!

$<=$

‥

Disease control

Cn

$\mathrm{Cr}$

$\mathrm{P}$

$\mathrm{Pa}$

Pn

Q

Qf

Qi

Sp

te

tv

V

$\mathrm{Vp}$

bees

avian

bovine

buffalo

canine

caprine

camel

equine

wild fauna (vertebrates)

feline

hare/rabbit

ovine

fur-bearing animals (in farms)

fish

swine

canine/feline

ovine/caprine

other

Never reported

Not reported

Year of last occurrence

Suspected but not confirmed

Exceptional occurrence

Low sporadic occurrence

Enzootic

High occurrence

Serological evidence and/or isolation of causative agent, no clinical disease

Disease exists; distribution and occurrence unknown

Confined to certain regions

Ubiquitous

Recognised in country for the first time

Only in imported animals (quarantine)

No information available

Control of non-vertebrate vectors

Control of wildlife reservoirs

Prohibition of import from infected countries

Control programme for only some areas of the country of certain types of breeding

Control programme for the whole country

Quarantine, movement control and other precautions at frontier and inside the country

Quarantine and other precautions at frontier

Quarantine measures and movement control inside the country

Stamping-out policy

Modified stamping-out policy

Treatment

Testing

Voluntary testing

Vaccination

Vaccination prohibited

Notifiable disease 